\title{
Livestock Held Farmers' Vulnerability and Adaptation to Climate Change in Case of Selected Zones, Oromia, Ethiopia
}

\author{
Oli Wakayo* Kassim Dedefo \\ Arsi University; College of Agriculture and Environmental Science, Asella, Ethiopia
}

\begin{abstract}
The climate change is increasing the frequent of droughts and sudden flooding. This research was aimed to assess the livestock induced farmers vulnerability and adaptation to climate change in Sikkoo-Mandoo societies in selected zones of Oromia region. The study sites and thirteen key informants were purposive selected whereas 64 households were selected by stratified random sampling. Stratifying household in to two traditional agro ecology zones they were randomly selected from each strata. Data were mainly collected by respondents' interview and reviewing of literatures, and analyzed by descriptive statistics. The cattle, poultry, donkeys, sheep, goat, horses and mule were the livestock found in study area. As evaluated by respondents from their experience the scarcity of water and fodders were caused highly vulnerable of livestock to extreme climatic events in winter and autumn season. Very high vulnerability were recorded in cattle types of livestock and communities livelihood. The vulnerability of farmers' livelihoods were related to the frequent exposure and high sensitivity of livestock to extreme climatic events. The medium livestock adaptive capacity in average were identified in general. The storing of straw, livestock mobility, herd splitting, using forest fodders and harvested/tap water were the livestock based climate change adaptation strategies used by majorities of farmers. Livestock based farmers' adaptation strategies were focused on livestock products and services. Their products are egg, milk and its product, using livestock dung for manure, meat, selling livestock and their products, and renting livestock labor as a source of income whereas their services includes the use of livestock in farming practice, transportation, and recreation for climate change adaptation. The first animals sold during crop fallers were poultry, sheep, goats, cattle and their products. Thus building climate change and variability's adaptive capacity of livestock have significant role in advancing climate resilient agriculture for sustainable farmers' livelihood.
\end{abstract}

Keywords: Adaptation, Extreme Climatic Event, Livestock's Vulnerability

DOI: $10.7176 / \mathrm{CER} / 11-4-04$

Publication date:May $31^{\text {st }} 2019$

\section{INTRODUCTION}

\subsection{Background of the study}

Climate change is realized by the changing in mean of temperature and precipitation within the long period of time. Vulnerability is a function of exposure, sensitivity and adaptive capacity of system to climate change. Adaptation refers to controlling and reducing the adverse effect of climate change (IPCC, 2012). The Earth's climate is changing, largely as a result of human activity. Both floods and droughts were frequent and more severe. The effect of climate change has been seriously affecting food production among the poor peoples of the world, particularly those in developing countries (Berhanu and Beyene, 2015). Most climate change models predict rising temperatures and decreasing rainfall in many dry-land areas result in the existence of water shortages for livestock, unpredictable rainfall and more frequent droughts and sudden flooding (ESAP, 2009).

The pastoral areas have faced major livelihood challenge from more frequent and severe droughts. In Ethiopia the situation is compounded by limited access to accurate climate and weather information. This increases exposure to famine, loss of lives and livelihoods, vector-borne disease and forced migration (Dedefo, 2019). As a result, the poorest and most vulnerable communities in Oromia region are more at risk to weather related natural hazards such as extreme droughts and flooding. Food security is a persistent problem exacerbated by drought. Between 1980 and 2000, for instance, three major droughts struck the lowlands of Eastern and Southern Ethiopia where pastoralist is a typical mode of life, where pastoralists lost up to two-thirds of their animals (PFE, 2010).

Livestock yields are directly affected by the frequency and severity of extreme climatic events like droughts, floods, and windstorms. Climate change could also lower the availability of forage, reduces livestock products and services (FAO, 2011). By changing the types, frequencies, and intensities of various pests and diseases, Climate change could also affects the health status of livestock (Flintan et al, 2011). The recurrent drought destroyed palatable fodder species for livestock and multi-faceted degradation of range resources has significant implications in terms of vulnerability to climate change and the food security of livestock (KVRT, 2009).

The climate change has also a substantial effect on water availability which in turn affects livestock drinking water sources. The decreasing precipitation combined with consecutive drought has led to chronic water scarcity across the area, leading to acute water crises (Hartmann and Sugulle, 2009). This profound sustainability problem for pastoral and agro-pastoral communities' livelihood. Climate change also affect livestock through 
facilitating the favorable conditions for the occurrence and outbreaks of severe diseases that could occur in previously unexposed animal populations (Davies and Roba, 2010). Moreover, changes in patterns and frequency of extreme events may affect both the distribution and the abundance of livestock disease vectors. It can also causes the occurrence of 'new diseases' livestock may be highly susceptible. For example, higher temperatures and drought may increase the rate of development of pathogens or parasites whereas changing wind patterns could affect the spread of certain pathogens and vectors (Gardner, 2012).

Climate changes was also caused losses of livestock and their productivity. The increased extent and duration of drought periods has considerably impacted the sustainability, viability and resilience of livestock systems and livelihoods. Livestock losses are expected during years of below average rainfall when forage productivity eroded (Gardner, 2012). The impacts of past droughts such as that of the 1972/73, 1984 and 2002/03, and floods in 2006 that caused substantial losses of livestock in many parts of Ethiopians. Over the last decade, prolonged and frequent drought recorded in Ethiopia was resulted in degradation rangeland resources and the consequent starvation and the death of livestock (FAO, 2011). According to PFE (2010) estimates the losses of livestock in different regions of the country during the severe drought of 2000 . The cattle mortality was $28 \%$ in Yaballo, 13\% in Dire, and 14\% in Teltelle and Arero districts of Oromia region. The impact of climate change is not equal for all livestock species, where browsers such as camel and goat are relatively less affected.

The quantity and quality of the livestock products are also affected by the shortage of rainfall and recurrent droughts in turn result in the shortage pasture and water for livestock. According to Calvosa (2009) climate change have affecting dairy, meat and wool production, mainly arising from its impact on grassland and rangeland productivity. During droughts pastoralists are faced with two tragic situations which affect their capacity to cope with the drought and feed their families. There is decreased herd productivity owing to the high mortality rate, reduced or no milk production, no calving, and animal weight loss that affects the market value of the livestock.

In climate change adaptation improvement of livestock products and services, and their adaptive capacity reduces farmers' vulnerability to climate change and promotes their sustainable livelihoods. The farmers are able to adapt the disasters where the prediction and early warning is available. Farmers have developed livestock based traditional adaptation mechanisms over the years which predominantly focused on management of their fodder and water. They have valuable traditional knowledge of effectively managing and utilizing livestock and their feed susceptible to the variable climates.

\section{MATERIALS AND METHODS}

\subsection{Description of study area:}

\subsubsection{Location of study area}

Sikko Mando Oromo's (can also called Arsi community) is target population found in four zones; dominantly in all districts (woredas) of Arsi, Bale, and west Arsi, as well as in Adami Tulu Jido Kombolcha woreda of East Shoa zones of Oromia regional state. Although the actual location of Sikko Mando Oromo's community are more than this, those selected for this study are the only those community found in thematic area of Arsi University. It is geographicaly located in between latitude of $5^{\circ} 48^{\prime} 5^{\prime \prime}$ to $9^{\circ} 8 ' 20^{\prime \prime} \mathrm{N}$ and longitudes of $37^{\circ} 24^{\prime} 20^{\prime \prime}$ to $40^{\circ} 44^{\prime} 20^{\prime}$ 'E in Oromia regional state of Ethiopia. Generaly, from the target population the area from which data were collected is the three zones drawn in the following figure-1. 


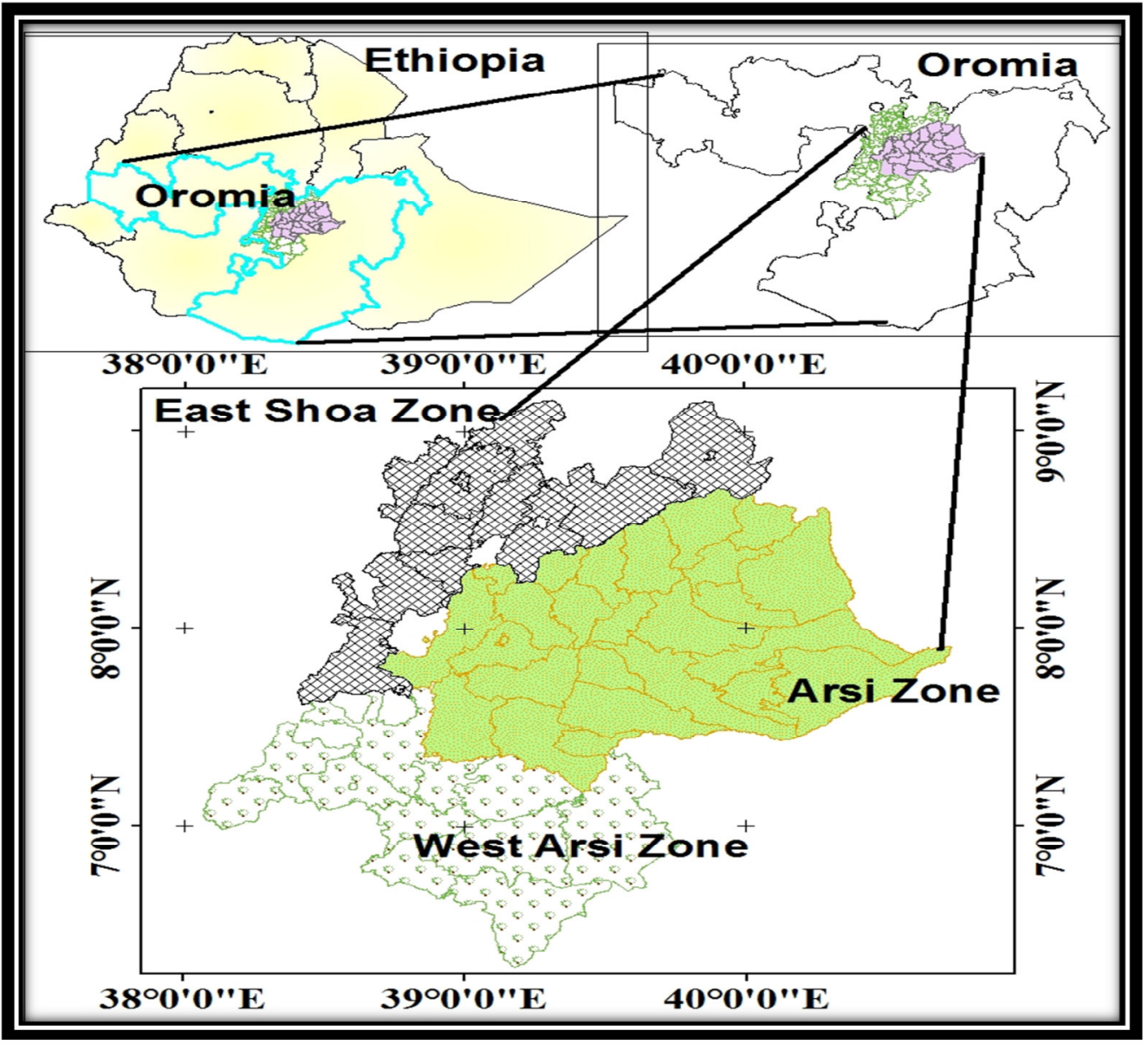

Figure 1: Location of study population (By arc map of GIS $v 10.3$ )

\subsubsection{Climate and Landscapes of the study area}

Sikko Mando community in thematic area of Arsi University are live in arid to humid climate, with dominance of sub-humid agro-climatic condition. The arid, semi-arid, sub-humid and humid are the traditional classification of climatic zone with the temperature varies from 11 and $28^{\circ} \mathrm{c}$. Some area have bimodal annual rainfall ranges from 500 to $3000 \mathrm{~mm}$ with a considerable climatic variability of among years (Dedefo, 2019). Furthermore, slight peak (39\%) of the annual rainfall occurring between March and May whereas main rainy-season is between Junes to August. The topography in the area is ranges from Rift-valley's rangelands to mountain ranges, with an altitude between 1500 and 3,800 m.a.s.l. The land use and land cover of study area was mainly cultivated, settlement, pasture, forest, swampy, lake, river, mountainous, etc. The vegetation of the area was commonly found in riverside, hillside and mountain (MOA, 2008). Natural trees/grass and planted vegetation were dominated by indigenous and eucalyptus species respectively.

\subsubsection{Socio-economic activities}

The major livelihood systems of the people is mixed Agriculture: crop farming and livestock rearing. Livestock remain the second most important economy of the Sikko Mandoo community. The main livestock reared are cattle, goat, sheep, camel, horse, mule, donkey and poultry. CSA (2013) also reported that out of total farmers in the study area, all of them were engaged in livestock production. The natural resources used for livestock feed have been managed by indigenous knowledge in Sikko Mando Oromo's Gadaa system.

\subsection{Sample size and Sampling Technique}

\subsubsection{Method of site selection:}

The Arsi, East Shoa and West Arsi zones were purposively selected for the research based on where Sikko Mandoo community live in from thematic area of Arsi University that supported the research financially. With regard to livestock production, it is the area prone to the recurrent droughts that become serious livelihood challenge for the community in the zones. Finally, the Woredas in which chief leaders of Gadaa system live in were the potential source of data. Based on these realities the study sites confirmed to be appropriate were purposively selected for the study. Finally, the same criteria and techniques were used to select sampled kebeles.

\subsubsection{Method of respondents Selection}

The key informants and household were the respondents from whom primary data were collected. The key 
informants such as chief leaders in Gadaa System and experts in government office were considered crucial source of basic information for this study. Chief leaders in Gadaa System were knowledgeable elders who lived in the area for long time and thus have credible knowledge of the area, culture, history in Gadaa System. During the study period, there were large community meetings at 'Dhadacha Qixibee' which is the second higher institution in Sikko Mandoo Gadaa system that took place for a week consecutively. It was arranged by Abbaa Gadaas and culture and tourism office of Arsi zones to be ready for power transfer between two Abbaa Gadaas and their gogesa (political party) at Odaa Robaa (the highest institution of Sikko Mandoo Gadaa system) found in Bale administration zone. The well-recognized chief leaders in Gadaa System were listed at the zones level. Those chief leaders and the experts on a position of the livestock production were purposively selected. Finally, household selection followed stratified random sampling strategies. Here stratifying households in to two traditional agro ecological zone (lowland and highland), then the households from each agro ecology were randomly selected. Thus, using this opportunity, thirteen key informants and 64 householders, those were 77 respondents in total, were selected for primary data collection.

\subsection{Data collection}

The study was used both qualitative and quantitative of primary and secondary data based on participatory approaches and combination of different tools. Primary data were gathered from study area by employing intensive household and key informant interviews. While secondary data were gathered by reviews of appropriate published and unpublished literatures.

\subsection{Data Analysis}

First of all the study utilized micro-soft excel during data entry and 'Statistical Package for Social Science' (SPSS) Software version 20 for the generation of result outputs. Then to analyze the quantitative data the study adapted descriptive statistics whereby the significance level were tested by analysis of variance. Finally, the qualitative data was also analyzed by descriptive statistics after interpretation and organization of the respondents' opinion.

\section{RESULT AND DISCUSSION}

\subsection{Types of livestock in study area}

There are many different types of livestock from which the cattle, poultry, donkeys, sheep, goat, horses and mule were commonly found in study area. The Cattle and Poultry were the livestock owed by all farmers (table-1). Consistent to this results similar livestock classification was reported by Jatani (2011). Similarly PFE (2010) reported that Ethiopia is home for about $12-15$ million pastoralists who reside in $61 \%$ of the nation's landmass. The pastoral areas are estimated to comprise $42 \%$ of the national total livestock population. Table 1: identified livestock in study area

\begin{tabular}{llcc}
\hline No & Major types of livestock & No of owners & \% \\
\hline 1 & Cattle & 77 & 100 \\
2 & Poultry & 77 & 100 \\
3 & Donkeys & 75 & 97.4 \\
4 & Sheep & 69 & 89.6 \\
5 & Goat & 66 & 85.7 \\
6 & Horses/mule & 39 & 50.6 \\
\hline
\end{tabular}

\subsection{Vulnerability to Climate change and Source of early warning information 3.2.1. Season vulnerability of livestock to extreme climatic condition}

In Oromo Gadaa system they are three months in four season of a year. The evidences of climate change and variability among different years and their seasons were reported by Dedefo (2019). Vulnerability is the characteristics and circumstances of a system or asset that make them susceptible to the extreme climatic condition. Livestock vulnerability thus can be the combination of the frequency of an extreme climatic event and its negative consequences against their adaptive capacity. According to Raagaas, the spiritual leaders in Sikkoo Mandoo Gadaa system, livestock were highly and frequently vulnerable to extreme climatic events in a last month of Bona/winter namely February and in the first two month of Badheesa/Autumn season, those are March and April (table-2). According to the respondents this livestock vulnerability were due to the scarcity of water and livestock feed in Bona, and shortage of their feed in Badheesa season. Similar seasonal classification and livestock vulnerability to climate variability in Borana zone were also reported by Negassa (2013). The detail temporal and spatial climate variability in Negele Arsi of central rift valley were also reported by Mekonnen, et al. (2017). 
Table 2: Livestock vulnerability as evaluated in different season of Gadaa system

\begin{tabular}{lllcc}
\hline No & Season in Gadaa system & Meaning & No.f resp. & \% \\
\hline 1 & Bona & Winter & 77 & 100 \\
2 & Badheesa/Arfaasaa & Autumn & 56 & 72.7 \\
3 & Ganna & Summer & 21 & 27.3 \\
4 & Biraa & Spring & 7 & 9.1 \\
\hline
\end{tabular}

\subsubsection{Livestock vulnerability to climate change}

Vulnerability of livestock to climate change were evaluated by respondents based on their life experience in five gadaa period (40 years). From the lists the very high livestock vulnerability to climate changes were recorded in cattle and high vulnerability were seen in horse types of livestock. As a result, significant vulnerability of livestock based farmers livelihood to climate change were recorded in study area. Low vulnerability of farmers livelihoods to climate change were recorded in poultry and goat types of livestock based community's livelihood. Very low vulnerability of farmers livelihoods to climate change were recorded in donkey types of livestock. The average of high vulnerability of livestock based farmers' livelihoods to climate change were recorded. The medium exposure and high sensitivity of livestock to extreme events were recorded from respondents' evaluation (table-3). The livestock and their products and services were highly sensitive to extreme climatic condition. The frequent droughts especially in the lowlands areas accelerating chronic vulnerability of livestock and farmers to food insecurity and famine for instance. In line to this finding the 12 years vulnerabilities to climate change mainly drought were seen in the past 30 years in Borana area reported by (ESAP, 2009 and Gardner, 2012). Negassa (2013) also showed the rising of temperature and slight decreasing of rainfall in the past four gadaa (32 years) from recorded annual rainfall data in Borana. The climate change have been affecting the livestock and their production systems in Ethiopia (Calvosa 2009; ESAP, 2009 and Davies and Roba 2010). Similarly the crop and livestock losses by droughts during 1998-2000, over North-Eastern Ethiopia were estimated at US\$266 per household, which is greater than the average annual income for $75 \%$ of the households in this region (FAO, 2011).

Table 3: Vulnerability of Livestock to climate change within five Gadaa periods

\begin{tabular}{|c|c|c|c|c|c|c|c|}
\hline Livelihoods types & Category & $\mathbf{N}$ & Mean & SE & SD & $\begin{array}{l}\text { Min. } \\
\text { value }\end{array}$ & $\begin{array}{l}\text { Max. } \\
\text { value }\end{array}$ \\
\hline \multirow{8}{*}{$\begin{array}{l}\text { Vulnerability of Livestock } \\
\text { to CC }\end{array}$} & Cattle & 77 & 4.8989 & 0.0505 & 0.46069 & 3.00 & 5.00 \\
\hline & Horse & 77 & 4.7997 & 0.05306 & 0.45337 & 2.00 & 5.00 \\
\hline & Sheep & 77 & 4.5813 & 0.05485 & 0.44454 & 2.00 & 5.00 \\
\hline & Donkey & 77 & 3.4234 & 0.07064 & 0.50783 & 3.00 & 5.00 \\
\hline & Mule & 77 & 3.4195 & 0.07066 & 0.52007 & 2.00 & 5.00 \\
\hline & Goat & 77 & 3.3377 & 0.07975 & 0.59982 & 3.00 & 4.00 \\
\hline & Poultry & 77 & 1.4994 & 0.08219 & 0.72122 & 0.00 & 2.00 \\
\hline & Mean & 77 & 3.70855 & 0.06595 & 0.52964 & 0.00 & 5.00 \\
\hline \multirow{3}{*}{$\begin{array}{l}\text { Exposure of Livestock to } \\
\text { extreme climate in five } \\
\text { gadaa terms }\end{array}$} & Extreme Rainfall & 77 & 3.8066 & 0.0565 & 0.66169 & 3.00 & 5.00 \\
\hline & Extreme Temperature & 77 & 2.7028 & 0.08232 & 0.35783 & 2.00 & 5.00 \\
\hline & Mean of extreme events & 77 & 3.2547 & 0.06941 & 0.50976 & 2.00 & 5.00 \\
\hline \multirow{3}{*}{$\begin{array}{l}\text { Sensitivity of Livestock to } \\
\text { extreme climate }\end{array}$} & Fodder shortage & 77 & 4.0067 & 0.0669 & 0.77978 & 3.00 & 5.00 \\
\hline & Water stress & 77 & 3.6739 & 0.06216 & 0.44897 & 2.00 & 5.00 \\
\hline & Mean & 77 & 3.8403 & 0.06453 & 0.61438 & 2.00 & 5.00 \\
\hline
\end{tabular}

\subsection{Livestock based climate change adaptation strategies of farmers}

Adaptation is a means of reducing the adverse impacts of climate change through exploiting the beneficial opportunities for farmers' livelihood. The livestock capacity to adapt climatic threat depends upon extent of adaptation required to eliminate or reduce the adverse consequences of climatic risk to an acceptable level. From list of livestock based climate change adaptation strategies, those used by very high number of farmers were storing of straw, livestock mobility and herd splitting. Using forest fodders like big trees leaves, harvested rainfall and/or tap water for livestock and indigenous early warning of drought were climate change adaptation strategies used by high number of farmers. However using resistant varieties and livestock destocking ways of climate change adaptation strategies were used by very few farmers. Generally the medium livestock's adaptive 
capacity to climate change in mean were identified by respondents' evaluation (table-4). Since all livestock species are not equally sensitive to the impacts of climate change, farmer have been diversifying the species of their herd and holding more climate resistant species, mainly browsers. During crop faller the first animals sold were usually poultry and their eggs, sheep and goats and followed by the cattle. In consistence of this finding (Calvosa, 2009; Hartmann and Sugulle, 2009; KVRT, 2009 and Negassa, 2013) reported that the mutual support systems, herd accumulation, livestock health progress, livestock supplementary feeding, herd and livelihood diversification, water trucking, rationing, restocking, construction of ponds and wells through a cash-for-work program, and slaughter destocking were used for climate change adaptation in Ethiopia. In pastoral livelihood of Ethiopia initiative of different NGOs were organizing pastoralists into saving and credit association and provide them with revolving funds. To ensure the role of livestock in climate change adaptation different the indigenous early warning system of Oromo Gadaa system were organized and ordered society around one political, economic, social, cultural, and religious institutions (SCUS, 2009 and WISP, 2010).

Table 4: Livestock management practices for enhancement of their adaptive capacity

\begin{tabular}{|c|c|c|c|c|c|c|c|}
\hline $\begin{array}{l}\text { Adaptation } \\
\text { strategies }\end{array}$ & Category & $\mathbf{N}$ & Mean & SE & SD & Min. value & Max. value \\
\hline \multirow{13}{*}{$\begin{array}{l}\text { Livestock based } \\
\text { adaptation strategies } \\
\text { of farmers }\end{array}$} & Store straw & 77 & 4.8961 & .03500 & .30713 & 4.00 & 5.00 \\
\hline & Livestock mobility & 77 & 4.8442 & .05566 & .48842 & 3.00 & 5.00 \\
\hline & Herd splitting & 77 & 4.7922 & .05944 & .52158 & 3.00 & 5.00 \\
\hline & Forest Fodders & 77 & 4.3766 & .14443 & 1.26739 & 1.00 & 5.00 \\
\hline & Water harvest/ using tap & 77 & 4.1039 & .03500 & .30713 & 4.00 & 5.00 \\
\hline & Indigenous early warning & 77 & 3.91 & .03800 & .30613 & 3.00 & 5.00 \\
\hline & Housing & 77 & 3.4805 & .12485 & 1.09557 & .00 & 4.00 \\
\hline & Spps diversification & 77 & 3.2597 & .07255 & .63666 & 3.00 & 5.00 \\
\hline & Pest diseases control & 77 & 2.8442 & .04161 & .36509 & 2.00 & 3.00 \\
\hline & Artificial Insemination & 77 & 2.7922 & .07917 & .69467 & .00 & 3.00 \\
\hline & Use resistant varieties & 77 & 1.0779 & .05777 & .50696 & .00 & 3.00 \\
\hline & Destocking & 77 & 0.2597 & .07255 & .63666 & .00 & 2.00 \\
\hline & Mean of adaptive capacity & 77 & 3.3864 & 0.0680 & 0.5944 & 0 & 5.00 \\
\hline
\end{tabular}

\subsection{Role of livestock in building Climate Change Adaptive capacity of farmers}

Capacity of society to adapt extreme climatic events depends upon the resources or assets available for adaptive responses. Respondents were identified and described the major way of livestock based climate change adaptation strategy used by farmers mainly during crop fallers. The egg, meat, milk and its product for food, use of livestock leather as mattress and livestock manure as compost and fuel wood were the major livestock products used for climate change adaptation of farmers. The use of livestock for farming practice, transportation and recreational services were the livestock services used for climate change adaptation of farmers. Selling livestock and their products, and renting livestock lobour were also used as a source of income for farmers' climate change adaptation during crop faller (table-5). According to Jatani (2011) the major livelihood assets of households in Dire district were livestock livelihood assets which serving the communities as alternative sources of income during critical drought period to sustain the livelihoods of the household. Alike the role of livestock and its products in controlling the negative impacts of climate change and become resilient from climatic shocks in this finding, Abdi (2010), Boru (2012), and Hurst et al., (2012) were also reported the pastoral livelihood diversification and food security. Similarly to this finding adaptation strategies of pastoral and agro-pastoral communities in Ethiopia was also reported by (Naess, et al., 2010 and Berhanu and Beyene, 2015). 
Table 5: Livestock based climate change adaptation strategies of farmers

\begin{tabular}{|c|c|c|c|c|}
\hline $\begin{array}{l}\text { Major role of } \\
\text { livestock }\end{array}$ & $\begin{array}{l}\text { Category of identified goods and } \\
\text { services of livestock }\end{array}$ & Types of livestock & $\begin{array}{l}\text { No of } \\
\text { respondents }\end{array}$ & $\%$ \\
\hline \multirow{12}{*}{$\begin{array}{l}\text { Use of livestock } \\
\text { products }\end{array}$} & \multirow[t]{3}{*}{ Milk and its product } & Cattle & 77 & 100 \\
\hline & & Goat & 68 & 88.3 \\
\hline & & Sheep & 36 & 46.8 \\
\hline & Egg & Poultry & 77 & 100 \\
\hline & Livestock dungs and its product & IPCC, 2012 & 77 & 100 \\
\hline & \multirow[t]{4}{*}{ Use of livestock meat } & Goat & 77 & 100 \\
\hline & & Sheep & 77 & 100 \\
\hline & & Poultry & 77 & 100 \\
\hline & & Cattle & 77 & 100 \\
\hline & \multirow[t]{3}{*}{ Use livestock leather as mattress } & Cattle & 77 & 100 \\
\hline & & Sheep & 31 & 40.3 \\
\hline & & Goat & 29 & 37.7 \\
\hline \multirow[t]{5}{*}{ Livestock services } & \multirow[t]{2}{*}{ Farming practice } & Cattle & 77 & 100 \\
\hline & & Donkeys/horses & 19 & 24.7 \\
\hline & \multirow[t]{2}{*}{ Transportation services } & Donkeys & 77 & 100 \\
\hline & & Horses/mule & 77 & 100 \\
\hline & Recreational services of horses & Horses/mule & 77 & 100 \\
\hline \multirow{4}{*}{$\begin{array}{l}\text { Livestock as a } \\
\text { source of income }\end{array}$} & Sell livestock & All livestock & 77 & 100 \\
\hline & Sell livestock products & & 77 & 100 \\
\hline & \multirow[t]{2}{*}{ Renting livestock lobour } & Cattle/Oxes & 9 & 11.7 \\
\hline & & Donkeys/horses & 6 & 7.8 \\
\hline
\end{tabular}

\section{CONCLUSION AND RECOMMENDATIONS}

The livestock in study area includes; cattle, poultry, donkeys, sheep, goat, horses and mule of which the cattle and poultry were the livestock owed by all farmers. Vulnerability to climate change is the combination of the probability of climatic extreme and its negative consequences. Vulnerability of livestock to climate change were evaluated by respondents based on their life experience within five gadaa system. Livestock's were highly vulnerable to climate change in February, March and April, those are a last months of Bona/winter season and the first two month of Badheesa/Autumn in Sikkoo Mandoo gadaa system because of scarcity of water and livestock feed. From the lists the high to very high livestock and their goods and services vulnerability to climate changes were recorded in horse and cattle types of livestock. This result in the significant vulnerability of livestock based farmers' livelihood to climate change. Low to very low vulnerability of livestock based farmers' livelihoods to climate change were recorded in farmers who mainly live on poultry, goat and donkey types of livestock and their goods and services. As evaluated by respondent average of high vulnerability of livestock based farmers' livelihoods to climate change were seen due to medium exposure and high sensitivity of livestock to extreme climatic events. Adaptation is a means of reducing vulnerability to climate changes. Thus farmers' capacity to adapt climatic threat depends upon extent of adaptation required to cope up with the adverse impacts of climatic risk to an acceptable level. The medium adaptive capacity in mean were indicated by respondent evaluation. The livestock based climate change adaptation strategies used by very high and high number of farmers were storing of straw, livestock mobility, herd splitting, using forest fodders, and harvested and/or tap water for livestock. According to respondents the major livestock products used in climate change adaptation strategy of farmers mainly during crop fallers were using egg, milk and its product, livestock dungs for manure, and meat. Use of livestock for farming practice, transportation and recreational services were also that of livestock services used in climate change adaptation. Selling livestock and their products, and renting livestock lobour were also the uses of livestock as a source of income for climate change adaptation. As respondents during crop faller the first animals sold are usually poultry, sheep, goats, cattle and their goods/services. As a result, building livestock's climate shocks adaptive capacity reduces farmers' vulnerability to extreme climatic events and plays an important role in progressing climate adaptation of agriculture for sustainable farmers' livelihood. 


\section{REFERENCES}

Abarufa Jatani, 2011. Climate change and variability and its impact on the livelihood of pastoralists: case study in Dire woreda of Borana zone, Oromia region. Addis Ababa University, Ethiopia.

Abdullah Abdi, 2010. Town Camels and Milk Villages: the growth of camel milk marketing in the Somali Region of Ethiopia. Future Agriculture (FAC) Research Update, Pastoralist Theme.

Calvosa, C., 2009. Livestock and climate change. International Fund for Agricultural Development (IFAD), Rome, Italy. Livestock thematic paper. www.ifad.org/lrkm/index.htm.

CSA, 2013. Welfare monitoring Survey, Summary Report. Federal Democratic Republic of Ethiopia (FDRE), Central Statistical Agency (CSA), Addis Ababa, Ethiopia.

Davies, J., and Roba, G., 2010. Compilation of Experiences in the Field of Climate Change Mitigation and Adaptation, Soil Management and Pastoralism in Dry and Sub-Humid Lands. IUCN, International Union for Conservation of Nature, Kenya. http://www.iucn.org/wisp.

Dejene Negassa, 2013. Local Institutions, External Interventions, and Adaptation to Climate Change: The case of the Borana pastoralists in southern Ethiopia. Research Backgrounder series, Oxfam America.

Ethiopian Society of Animal Production (ESAP), 2009. Climate change, livestock and people: Challenges, opportunities, and the way forward. Aynalem, H., and Zelalem, Y., (Eds). Proceedings of the 17th Annual conference held in Addis Ababa, Ethiopia, September 24 to 26, 2009. ESAP, Addis Ababa 300 pp.

FAO, 2011.Strengthening Capacity for Climate Change Adaptation in the Agriculture Sector in Ethiopia. Food and Agriculture Organization of the United Nations, Rome. Proceedings from National Workshop held in Nazreth, Ethiopia5-6 July 2010.

Flintan, F., Boku Tache and Abdurehman Eid, 2011. Rangeland fragmentation in traditional grazing areas and its impact on drought resilience of pastoral communities: Lessons from Borana, Oromia and Harshin, Somali Regional States, Ethiopia. REGLAP (Regional Learning and Advocacy Programme).

Gardner, I., 2012. Pastoralist Access to Livestock Health Services in Tanzania: Implications for Climate ChangeDriven Disease. Colorado State University Fort Collins, CO 80523-1644.

Halake Boru, 2012. Pastoral livelihood diversification and food security: The case of Yabalo woreda, Oromia National Regional State. Masther's thesis. Ethiopian Civil Service University, Addis Ababa, Ethiopia.

Hartmann, I., and Sugulle, A., 2009. The Impact of Climate Change on Pastoral Societies of Somaliland. Candlelight for Health, Education \& Environment, Somalia.

Hurst M., Jensen N., Pedersen S., Sharma A., Zambriski J., 2012. Changing Climate adaptation strategies of Boran pastoralists in southern Ethiopia. Working paper no. 15 Cali, Colombia: CGIAR Research Program on Climate Change, Agriculture and Food Security (CCAFS). www.ccafs.cgiar.org.

IPCC, 2012. Managing the Risks of Extreme Events and Disasters to Advance Climate Change Adaptation. A Special Report of Working Groups I and II of the Intergovernmental Panel on Climate Change. Cambridge University, Cambridge, UK, and New York, USA, 582pp.

Kassim Dedefo, 2019. Comparative analysis of climate change evidences and simulation of Sikko-Mando Gadaa systems in selected zones of Oromia. Arsi University, Ethiopia.

KVRT, 2009. Enhancing adaptive capacity of pastoralists to climate change induced vulnerability in northern Kenya. Preliminary findings of a study undertaken between January 2008 and December 2009. KVRT (Kenya Vulnerability Research Team), Turkana, Kenya.

MOA, 2008. Relief interventions in pastoralist areas of Ethiopia. Minster of Agriculture and Rural Development. Addis Ababa, Ethiopia. 48p.

Naess, O., Sullivan, M., Khinmaung, J., Philippe C., Otzelberger A., 2010. Changing Climates Changing Lives: Adaptation Strategies of Pastoral and Agro-pastoral Communities in Ethiopia and Mali. Action Contre La Faime, International.

PFE, 2010. Climate change and Pastoralism: Implication for sustainable pastoral development. Pastoralist Forum Ethiopia. Report of $5^{\text {th }}$ National Conference on Pastoralism, Addis Ababa, Ethiopia.

SCUS, 2009. (Eds: Abebech Belayneh, Dr. EtsehiwotWondimu, Dr. KebaduSimachew, Edward Stevens). Camel Distribution in Response to Climate Change: Case studies from Moyale District (Liben Zone, Somali Regional State)and Dhas and Arero Districts (Borana Zone, Oromiya Regional State) of southern Ethiopia.Pastoral Livelihoods Brief \#1. Save the Children United State.

Wassie Berhanu and Fekadu Beyene, 2015. Climate Variability and Household Adaptation Strategies in Southern Ethiopia. Journal of Sustainability, ISSN 2071-1050.

WISP, 2010. Building climate change resilience for African livestock in sub-Saharan Africa. World Initiative for Sustainable Pastoralism (WISP): a program of IUCN - The International Union for Conservation of Nature, Eastern and Southern Africa Regional Office, Nairobi. ISBN: 978-2-8317-1260-4.www.iucn.org/wisp.

Zenebe Mekonnen. Teshale Woldeamanuel, Zebene Asfaw and Habtemariam Kassa, 2017. Analysis of observed and perceived climate change and variability in Arsi Negele District, Ethiopia. Environ Dev Sustain (2018) 20:1191-1212. 